\title{
CONSUMER BEHAVIOR AND THE EFFECTS OF THE SUPPLY OF FRENCH CULTIVARS OF POTATOES
}

\author{
COMPORTAMENTO DOS CONSUMIDORES E OS EFEITOS DA OFERTA DE \\ CULTIVARES FRANCESAS DE BATATAS
}

\author{
Rita de Cássia RIBEIRO ${ }^{1}$; Helena Maria PINHEIRO-SANT'ANA ${ }^{2}$; \\ Joaquim Gonçalves de PÁDUA ${ }^{3}$; José Benicio Paes CHAVES ${ }^{4}$ \\ 1. Professor, PhD., Federal University of Minas Gerais - UFMG, Belo Horizonte, MG. ritaribeiro@ufmg.br; \\ 2. Professor, PhD., Federal University of Viçosa - UFV, Viçosa, MG; 3. PhD., Technological Center of Potatoes and Strawberries, \\ Agricultural Research Corporation of Minas Gerais - EPAMIG, Pouso Alegre, MG, Brasil; 4. Professor, PhD., Federal University of \\ Viçosa - UFV, Viçosa - MG, Brasil.
}

\begin{abstract}
The present work aimed to analyze the factors that affect the purchase of potatoes in Belo Horizonte city, Brazil, and the effects of the availability of many different French cultivars to this market. In France, there is a large variety of potatoes with different shapes, skin colors and textures and indications for different culinary uses. Therefore, cluster analysis was performed and a mixed effects linear regression model was adjusted to analyze the factors that can influence the purchase of potatoes by consumers. The factors analyzed were the size, skin color and texture and the presence of information about the cultivar name, culinary use and seal of quality. Age, education, region and income were important parameters in determining a groups' intent to purchase, and factors such as potato shape, skin color and presence of a seal of quality were significantly important in the analysis. The presence of information related to the name of the cultivar and recommended culinary use had no significant effect on purchase intention. Last, the introduction of new French potato cultivars into such markets as Belo Horizonte city should be preceded by an educational process to prepare consumers to receive information regarding the recommended culinary use of potatoes and the final sensory quality of the preparations illustrated with these potatoes.
\end{abstract}

KEYWORDS: Potato. French cultivars. Consumers' behavior. Cluster analysis.

\section{INTRODUCTION}

The potato (Solanum tuberosum, L.) is considered the fourth most important food worldwide (FAO, 2009). In addition to its multiple culinary uses, it is rich in complex carbohydrates, food fibers and has low biological value proteins and micronutrients, mainly potassium, phosphorus and vitamin $\mathrm{C}$ (NÚCLEO DE ESTUDOS E PESQUISA EM ALIMENTAÇÃO, 2011).

In France, potatoes are purchased and consumed according to specific culinary use, and the French deeply appreciate their taste, regardless of physical characteristics such as size, shape and skin color (CONTAMINE, 2008); this taste appreciation favored the development and trade of different cultivars with specific characteristics for different culinary uses. In Brazil the opposite is observed, where potatoes are mainly acquired based on their physical appearance.

Studies carried out by Prescott et al. (2002), Akbay et al. (2007), Sveinsdóttir et al. (2009), Honkanen and Frewer (2009) and Ares et al. (2010) aimed to analyze the behavior of consumers regarding several food products and to understand the factors that determine selection of different foods. These factors are related not only to food sensory aspects but also to individual experiences, demographic characteristics, culture, health, price and convenience (ENNEKING et al. 2007).

Regarding potato consumption, few works in the scientific literature have aimed to identify, even indirectly, the factors (extrinsic and intrinsic) affecting recognition of the need, the search for information, the evaluation of pre-purchase alternatives, purchase, consumption and post consumption evaluation.

Due to the relevance of the potato culture and the scarcity of studies on potato consumers, the present study aimed to investigate the factors that affect the purchase of potatoes in Belo Horizonte city, Minas Gerais, Brazil, as well as to analyze the effects of offering French cultivars to this market and to discuss possible strategies for the inclusion of this product in this market. It is believed that such information will assist the sector in offering new products and establishing efficient marketing strategies. 


\section{MATERIAL AND METHODS}

\section{Definition of the factors (and their levels) that affect the purchase of potatoes}

The main factors involved in the purchase of potatoes were defined in previous stages of this research (Table 1) by means of focus groups carried out with housewives, restaurants owners and gastronomy students, and sensory tests of acceptance and intent to purchase specific French potatoes for frying, cooking and puree. From these preliminary studies, it was established that the most influential factors in the process of potato purchase and consumption were related to the potato's physical characteristics, such as size, shape and skin color and texture, and product information available, such as cultivar name, culinary use and seal of quality. Thus, the present study aimed to evaluate these factors by joint factor analysis. For this purpose, two levels were established for each factor (Table 1).

Table 1. Factors (and their respective levels) that affect the purchase of potatoes

\begin{tabular}{ll}
\hline \multicolumn{1}{c}{ Factors } & \multicolumn{1}{c}{ Levels } \\
\hline Shape & 0 - Irregular \\
Skin color and texture & 1 - Regular \\
& 0 - Rough, opaque and dark \\
Information on the cultivar name and culinary use & 1 - Smooth, bright and light \\
& 0 - Absence \\
Seal of quality & 1 - Presence \\
& 0 - Absence \\
& 1 - Presence \\
\hline
\end{tabular}

A random selection was carried out to determine the images analyzed by the participants of the study. The complete data profile of the collection method was used in the definition of the treatments (GREEN \& SRINIVASAN, 1978). Thus, treatments were obtained by the combination of the factor levels; sixteen cards were elaborated according to the descriptions of the treatments.

\section{Elaboration of the combinations of the factors evaluated}

The Ágata cultivar, widely commercialized in Belo Horizonte city, with its appearance already known to consumers, was used to illustrate the sixteen cards for analysis, as shown in Figure 1. Regular and irregular shaped potatoes of this cultivar were photographed. Based on these images, cards with figures created by the combination of the factors were illustrated using the Corel $^{\circledR}$ software system. Each card measured $10 \mathrm{~cm}$ long and $9 \mathrm{~cm}$ wide and was given a random code, which was in the lower left edge of the figures. Below each figure, there was a $9 \mathrm{~cm}$ non-structured scale to measure the intent-to-purchase of each. Figure 1 presents some examples of the cards evaluated by the interviewees.

Composition of the questionnaire used for data collection and evaluation of the relative importance of the factors related to the purchase of potatoes
A questionnaire used for acquisition of socioeconomic data was employed to characterize the population studied, including gender, age and education level of the interviewees and of the heads of the households, as well as their professional activity, family income, and other questions about acquisition, preparation and potato consumption habits. To estimate the purchasing power of urban families who conformed to ABEP (2008), there was a verification of the number of possessions, such as televisions, radios, bathrooms, cars, maids, washing machines, VCRs and/or DVDs, refrigerators and freezers present in the households to determine their ranking, according to the Brazilian Economic Classification Criterion (CCEB).

Consumer interviews regarding potatoes were conducted with those responsible for the purchase and/or preparation of potatoes in households of the following nine regions of the city of Belo Horizonte: mid-south, northwest, northeast, east, Venda Nova, Pampulha, Barreiro, north and west. The size of the sample was established based on the population of Belo Horizonte-2.3 million inhabitants, according to the survey of the Brazilian Institute of Geography and Statistics carried out in 2000. The confidence interval was fixed at $95 \%$ and the margin of error at 5\% (LEVIN, 1987). According to the sampling calculation, 401 questionnaires were distributed. As a safety measure, an additional 5\% was applied, totaling 421 questionnaires. 
The household interviews were carried out between March 9 and 21, 2009, by interviewers trained at the Center of Applied and Compared Socio-political Studies of the Federal University of Ouro Preto, Minas Gerais, Brazil.

Before the evaluation of the cards, the interviewees were advised to behave as if they were in a store to purchase potatoes. The sixteen cards were presented individually in a completely
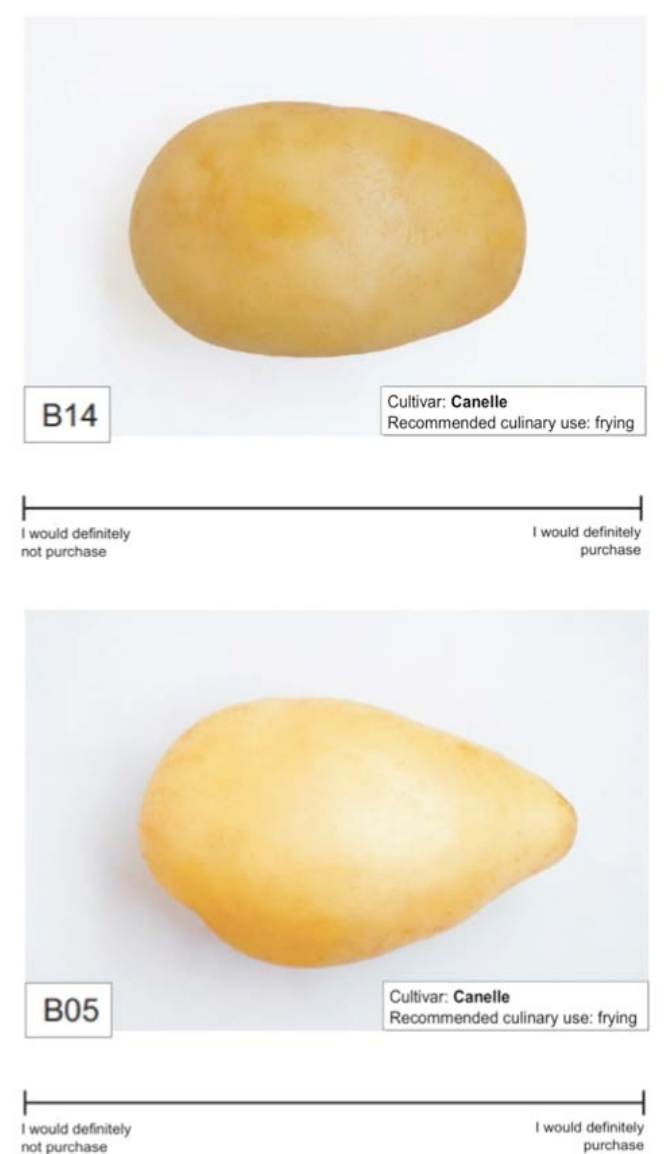

Figure 1. Examples of cards evaluated by the interviewees.

\section{Statistical Analysis}

The responses marked on the scale for evaluation of the intent-to-purchase of each card were transformed into scores, zero to nine.

A cluster analysis was initially performed by the Ward method to define the adequate number of clusters (MINGOTI, 2007). Next, the nonhierarchical K-means method was applied using the Hartigan-Wong algorithm (HARTIGAN; WONG, 1979).

Considering the intent-to-purchase score as the dependent variable, groups were formed by cluster analysis; factors of shape, physical characteristics of the skin, presence or absence of information on culinary use and presence or absence of a seal of quality were the independent variables. A mixed effects linear regression model was fit to randomized design (MACFIE; BRATCHELL, 1989), and the intent to purchase was evaluated. Each figure contained a $9-\mathrm{cm}$ non-structured scale consisting of two anchors at the extremities. The left extremity presented the statement "I would definitely not purchase" and on the right, "I would definitely purchase". The interviewees were told to mark the scale with a vertical line, according to their purchase intent for each set of factors presented.

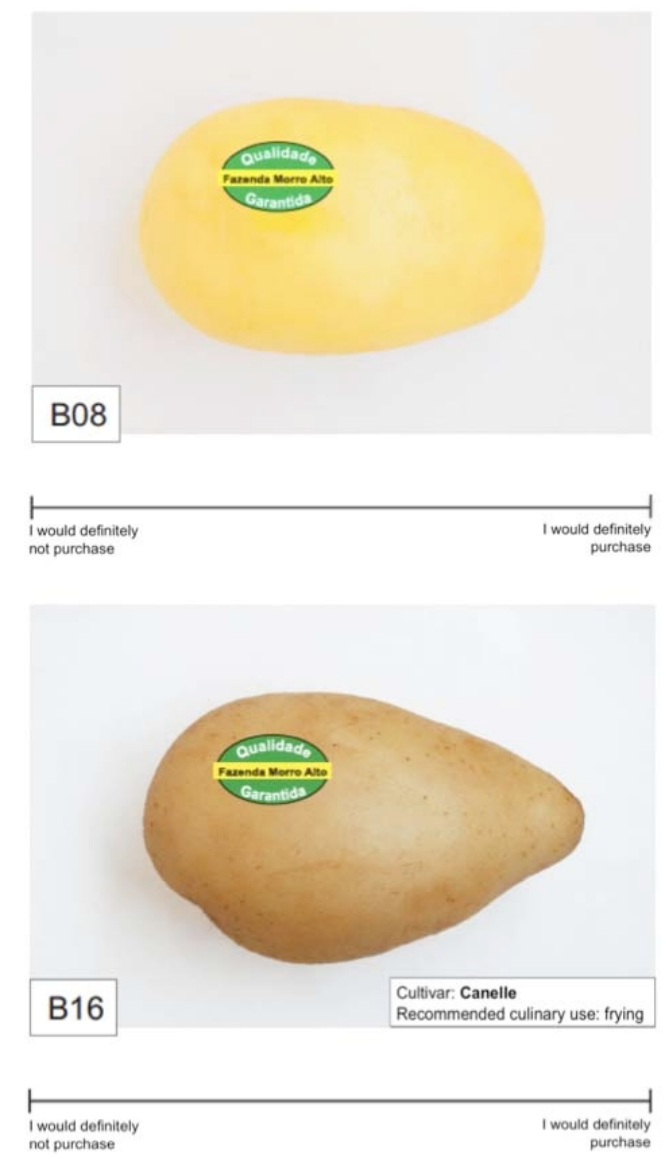

the data, where the intercept was the random effect. Two models were fitted, one with and one without the groups of the cluster analysis.

The parameters of the models were estimated using the $\mathrm{R}$ Development Core Team (2009) software system. The lme() function of the nlme (PINHEIRO et al., 2008) package was used to estimate this model.

The adjusted model can be written as follows:

$Y_{i j}=\mu_{0}+\mu_{i}+\beta_{1} * F 1_{i}+\beta_{2} * F 2_{i}+\ldots+\beta_{p} * F p_{i}+\varepsilon_{i j}$

where $Y_{i j}$ is the score in the treatment $\mathrm{j}$ given by the individual i, $\mu_{0}$ is the average score of all individuals when all of the levels of the factors are zero, $\mu_{i}$ is the random effect of the individual $i$ with 
zero average and variance $\sigma_{\mu}$, being the addition to the average score of the individual $i$, in other words, how much this individual varies in relation to the average of all, $\beta_{k}$ is the effect of the factor $k\{k=1$, $2, \ldots, p\}, F k_{i}$ is the presence of the factor $k$ in the individual $i\{k=1,2, \ldots, p\}, \varepsilon_{i j}$ is a random error with zero average and variance $\sigma_{\varepsilon}$.

In addition to the estimation of the model parameters, it is also important to estimate the variance of the estimates of the effects of the factors, $\beta_{k}, k=1,2, \ldots, p$. Based on the variances estimates of the effects, it is possible to test if the effects are significant.

Analysis of the data of the Brazilian Economic Classification Criterion (CCEB) was carried out according to a scoring system (ABEP, 2008). For the construction of the CCEB, the regression analysis of family income was considered according to the possession of items and educational level of the heads of the families. The minimum score was zero and the maximum score was 46 points. Thus, it was possible to categorize the households into eight economic classes, considering that class is a family characteristic.

The other data, including gender, age and education level of the interviewees and of the heads of the households, as well as their professional activity, family income, and other questions about acquisition, preparation and potatoes consumption habits, were obtained from the questionnaire. These data were tabulated and submitted to the analysis of frequency for the characterization of the population studied. For such analysis, the SPSS Professional Statistics 17.0 software system was used.

\section{RESULTS AND DISCUSSION}

\section{Socioeconomic characterization of the participants in the study}

Of those participating in this study, $79.1 \%$ were female and $20.9 \%$ were male. Most interviewees $(71.1 \%)$ were between 25 and 59 years old. These data were expected because the participants of this study were those responsible for the purchase or preparation of potatoes in the evaluated households.

Regarding the educational level, only $25.4 \%$ of the interviewees declared having graduated from high school, and $8.1 \%$ from college. Considering family income, for $72.9 \%$ of the interviewees, the sum of the monthly income of all of the residents in the households was between 1 and 5 Brazilian minimum salaries, ranging between $\mathrm{R} \$ 415.00$ and
$\mathrm{R} \$ 2,075.00$ (US\$ 180.00 to US\$ 900.00) for March 2009.

The CCEB, which estimates the purchasing power of urban populations, was applied in $99.8 \%$ of the households evaluated in this research. Most families were categorized between the classes $\mathrm{C} 1$ and C2 (61.3\%), which is in agreement with the family income declared in the present research. The sum of the families categorized between the classes $\mathrm{B} 1$ and $\mathrm{C} 2$ corresponded to $86.8 \%$ of the households analyzed. According to this criterion (ABEP, 2008), families between classes $\mathrm{B} 1$ and $\mathrm{C} 2$ present an income between $\mathrm{R} \$ 3,479.00$ and $\mathrm{R} \$ 726.00$ (US\$ $1,510.00$ to US\$ 315.00$)$, respectively.

\section{Cluster analysis}

From the cluster analysis, using the principle of parsimony, four groups were selected. . The most pronounced characteristics of each group are as follows:

- Group 1 (85 individuals): Greatest concentrations of individuals over 45, low education, lower income, less knowledge regarding the location of origin of the potatoes and the seal of quality, less interest in obtaining information about the best way to prepare potatoes, and a smaller percentage of people who would pay more for potatoes with this type of information. This is the group that least consumes potatoes, and presented the highest dissatisfaction with the high price of the product.

- Group 2 (91 individuals): Highest concentration of people between 25 and 34 who live in the northeast section of the city, and the most common education level is complete and incomplete primary schooling, low income, predominant $\mathrm{C}$ rating of the CCEB and increased knowledge about the location of origin of the potato. For this group it is important to present information at the time of purchase on the type of potato. The biggest complaint was regarding potatoes presenting rotting portions at the time of purchase.

- Group 3 (98 individuals): Higher concentrations of people living in the western region of the city, the education level is frequently between complete and incomplete secondary schooling, the predominant income group is between $\mathrm{R} \$$ 830.00 and R\$ 2,075.00 (US\$ 360.00 to US\$ 900.00) and the CCEB classification is predominantly $\mathrm{C}$. This group presents the greatest dissatisfaction with the poor quality of potatoes at the time of purchase.

- Group 4 (94 individuals): Higher education, higher income, predominantly CCEB criterion of 
$\mathrm{B}$ and $\mathrm{A}$, believe it is important that information is shown on the type of potato, greater knowledge about the quality seal. At the time of purchase, this group would like more information about the expiration date, nutritional information, source and is the group that consumes the greatest quantity of potatoes.
Relative importance of factors related to the purchase of potatoes together with consumers

After the cluster analysis, a linear mixed effects model was fit, considering the groups encountered in this analysis. Table 2 shows that the groups found in the cluster analysis and the factors of potato shape, aspects of the skin and seal of quality were significant in explaining the variation in scores of intent to purchase.

Table 2. Analysis of variance for the linear model with mixed effects for intention to purchase with the groups of the cluster analysis

\begin{tabular}{lcccc}
\hline & $\begin{array}{c}\text { Degrees of freedom } \\
\text { of the numerator }\end{array}$ & $\begin{array}{c}\text { Degrees of freedom } \\
\text { of the denominator }\end{array}$ & F & p-value \\
\hline${\text { Intercept }\left(\beta_{0}\right)}$ & 1 & 5480 & 5380.87 & $<0.001$ \\
Group $^{\text {a }}$ & 3 & 364 & 2.66 & 0.048 \\
Shape of the potato $^{\mathrm{b}}$ & 1 & 5480 & 317.43 & $<0.001$ \\
Aspects of the skin $^{\mathrm{c}}$ & 1 & 5480 & 270.61 & $<0.001$ \\
Information $^{\mathrm{d}}$ & 1 & 5480 & 0.40 & 0.529 \\
Seal of quality $^{\mathrm{e}}$ & 1 & 5480 & 117.36 & $<0.001$ \\
\hline
\end{tabular}

${ }^{a}$ Groups encountered in the cluster analysis. ${ }^{b}$ Potato with regular shape. ${ }^{c}$ Tubercles with light, smooth and bright skin. ${ }^{d}$ Presence of information on the cultivar name (Canelle) and specific culinary use (frying). ${ }^{\mathrm{e}}$ Potato with seal of quality.

When analyzing the model presented in Table 3, which contains the fixed part of the fitted mixed model, groups 2,3 and 4 present a higher intent to purchase than the first group, where this difference is statistically significant. As the differences of $\beta$ between groups 2,3 and 4 are small, there appears to be no significant difference among them. It can also be noted that the factors of potato shape, aspects of the skin and seal of quality significantly increase the mean score of intent-topurchase, while the information factor is not statistically significant. Analyzing the random part, the variation in intent to purchase is within the same individual and not between individuals.

Table 3. Linear model of the mixed effects for intent to purchase with the fixed effects

\begin{tabular}{|c|c|c|c|c|c|c|}
\hline \multirow{2}{*}{ Intercept $\left(\beta_{0}\right)$} & & Value $\beta$ & SE & DF & t-value & p-value \\
\hline & & 2.654 & 0.138 & 5480 & 19.238 & 0.0000 \\
\hline \multirow{3}{*}{$\begin{array}{l}\text { Cluster } \\
\text { Analysis }\end{array}$} & Group $2^{\mathrm{a}}$ & 0.413 & 0.171 & 364 & 2.411 & 0.0164 \\
\hline & Group $3^{a}$ & 0.422 & 0.168 & 364 & 2.508 & 0.0126 \\
\hline & Group $4^{\mathrm{a}}$ & 0.334 & 0.170 & 364 & 1.964 & 0.0502 \\
\hline \multirow{4}{*}{$\begin{array}{l}\text { Joint Factor } \\
\text { Analysis }\end{array}$} & Shape of the potato ${ }^{b}$ & 1.113 & 0.062 & 5480 & 17.824 & 0.0000 \\
\hline & Aspects of the skin ${ }^{c}$ & 1.028 & 0.062 & 5480 & 16.462 & 0.0000 \\
\hline & Information $^{\mathrm{d}}$ & -0.040 & 0.062 & 5480 & -0.644 & 0.5193 \\
\hline & Seal of quality ${ }^{e}$ & 0.677 & 0.062 & 5480 & 10.833 & 0.0000 \\
\hline
\end{tabular}

Standard deviation: $\beta_{0}=0.93(14.0 \%)$; Residue $=5.71(86.0 \%) ;{ }^{a}$ Groups encountered in the cluster analysis. ${ }^{b}$ Potato with regular shape. ${ }^{c}$ Tubercles with light, smooth and bright skin. ${ }^{d}$ Presence of information on the cultivar name (Canelle) and specific culinary use (frying). ${ }^{\mathrm{e}}$ Potato with seal of quality. $\mathrm{DF}=$ Degrees of freedon. $\mathrm{SE}=$ Standard error.

Based on the significant variables, the presence of possible interactions was verified, which may explain the variation of intent to purchase, as presented in Table 4.

A significant interaction was verified between the factors of aspects of the skin and the groups formed by the cluster analysis. Thus, the model presented in Table 5 was established.
Analyzing the fixed portion of the fitted mixed model, it follows that groups 2, 3 and 4 have a higher intent to purchase than group 1 . It can also be noted that the factors of potato shape, aspects of the skin and a seal of quality continue to significantly increase the average score of intent to purchase. 
Table 4. Analysis of variance for the mixed effects linear model with all interactions for the intent to purchase

\begin{tabular}{|c|c|c|c|c|}
\hline Source & $\begin{array}{c}\text { Degrees of } \\
\text { freedom of } \\
\text { the } \\
\text { numerator }\end{array}$ & $\begin{array}{c}\text { Degrees of } \\
\text { freedom of } \\
\text { the } \\
\text { denominator }\end{array}$ & $\mathbf{F}$ & p-value \\
\hline Intercept $\left(\beta_{0}\right)$ & 1 & 5469 & 5380.193 & $<0.0001$ \\
\hline Group $^{\text {a }}$ & 3 & 364 & 2.657 & 0.0482 \\
\hline Shape of the potato ${ }^{b}$ & 1 & 5469 & 320.343 & $<0.0001$ \\
\hline Aspects of the skin ${ }^{c}$ & 1 & 5469 & 273.089 & $<0.0001$ \\
\hline Seal of quality ${ }^{\mathrm{d}}$ & 1 & 5469 & 118.419 & $<0.0001$ \\
\hline Group * Shape of the potato & 3 & 5469 & 0.442 & 0.7228 \\
\hline Group * Aspects of the skin & 3 & 5469 & 16.757 & $<0.0001$ \\
\hline Group $*$ Seal of quality & 3 & 5469 & 1.293 & 0.2749 \\
\hline Shape of the potato $*$ Aspects of the skin & 1 & 5469 & 3.441 & 0.0663 \\
\hline Shape of the potato $*$ Seal of quality & 1 & 5469 & 1.879 & 0.1705 \\
\hline Aspects of the skin * Seal of quality & 1 & 5469 & 0.482 & 0.4876 \\
\hline
\end{tabular}

${ }^{a}$ Groups encountered in the cluster analysis. ${ }^{b}$ Potato with regular shape. ${ }^{c}$ Tubercles with light, smooth and bright skin. ${ }^{\mathrm{d}}$ Potato with seal of quality.

Table 5. Mixed effects linear model with interactions for the intent to purchase with the fixed effects

\begin{tabular}{|c|c|c|c|c|c|c|}
\hline & & Value $\beta$ & SE & DF & t-value & p-value \\
\hline \multicolumn{2}{|c|}{ Intercept $\left(\beta_{0}\right)$} & 2.277 & 0.149 & 5477 & 15.29 & 0.0000 \\
\hline \multirow{3}{*}{$\begin{array}{l}\text { Cluster } \\
\text { Analysis }\end{array}$} & Group $2^{a}$ & 0.788 & 0.193 & 364 & 4.08 & 0.0001 \\
\hline & Group $3^{a}$ & 1.007 & 0.190 & 364 & 5.30 & 0.0000 \\
\hline & Group $4^{\mathrm{a}}$ & 0.836 & 0.192 & 364 & 4.36 & 0.0000 \\
\hline \multirow{3}{*}{$\begin{array}{l}\text { Joint } \\
\text { Analysis }\end{array}$} & Shape of the potato ${ }^{b}$ & 1.113 & 0.062 & 5477 & 17.91 & 0.0000 \\
\hline & Aspects of the skin ${ }^{c}$ & 1.782 & 0.129 & 5477 & 13.80 & 0.0000 \\
\hline & Seal of quality ${ }^{\mathrm{d}}$ & 0.677 & 0.062 & 5477 & 10.88 & 0.0000 \\
\hline \multirow{3}{*}{ Interaction } & $\begin{array}{l}\text { Group } 2 * \text { Aspects of the } \\
\text { skin }\end{array}$ & -0.751 & 0.180 & 5477 & -4.18 & 0.0000 \\
\hline & $\begin{array}{l}\text { Group } 3 * \text { Aspects of the } \\
\text { skin }\end{array}$ & -1.171 & 0.177 & 5477 & -6.63 & 0.0000 \\
\hline & $\begin{array}{l}\text { Group } 4 * \text { Aspects of the } \\
\text { skin }\end{array}$ & -1.005 & 0.178 & 5477 & -5.63 & 0.0000 \\
\hline
\end{tabular}

Standard deviation: $\beta_{0}=0.93(14.0 \%)$; Residue $=5.65(86.0 \%) ;{ }^{a}$ Groups encountered in the cluster analysis. ${ }^{b}$ Potato with regular shape.

${ }^{\mathrm{c}}$ Tubercles with light, smooth and bright skin. ${ }^{\mathrm{d}}$ Potato with seal of quality. DF $=$ Degrees of freedon. SE $=$ Standard error.

When evaluating the interactions, it is noted that when the factor of aspects of potato skin is present in group 1, the difference between groups decreases; group 1 may even present an average intent to purchase greater than groups 2,3 and 4 with the presence of the factor aspects of the skin. This suggests that group 1 attributes a great importance to the aspects of the skin when compared to other groups. Still, when analyzing the random part, that greatest portion of variation in the intent to purchase is found within the same individual and not between individuals.

A low intent to purchase of the people in group 1, which could be characterized as a group or social class of low income and schooling in Brazil, indicates a relationship between the characteristics of this group and its possible aversion to differentiated products. This different behavior may be related to pre-concept, lack of cultural identity or other socio-economic factors.

Socio-economic factors affect purchasing decisions, as do the intrinsic characteristics of the products (ENNEKING et al., 2007). In belonging to a particular social group or category, people may adopt different standards of conduct, which lead to different consumption choices.

According to Akerlof and Kranton (2000) the identity "is a set of factors that characterizes the 
people" and influences their decisions by means of behavior norms linked to social categories to which the person identifies. Thus, people act motivated from a concern to maintain their group identity, following social norms that shape their behavior, even in acts of consumption. This factor can be crucial when studying the behavior of people in each region of a city (described in this study) and must have been decisive in the selection pattern for group 1 of the cluster analysis.

In this case, the rejection of potatoes with darker and rough skin is a behavior of persons belonging to group 1, which is not repeated in other groups. This behavior can be classified as an aversion that governs the behavior of a particular group, and would have to be researched if there was interest to act in this niche market. Another possible hypothesis in relation to group 1 is that they fit into a situation of low income close to what some economists classify as the "poverty line." In such cases, the choices of consumption may be affected because of the immediate need of basic commodities, which has not been met.

Parallel to this view of inequality based on analysis of income, the notion of inequality based on capabilities can be highlighted. In this field, Sen (2008) notes that the "basic inadequacy that causes poverty is relative to have minimally adequate capacities." Therefore, sections of the population are guided not only by the choices offered to everyone but also by the goods they actually "want to get." According to Sen (2008), the concept of freedom freedom of choice - "is strongly dependent on the ability of people to intelligently understand and choose from alternatives they really possess."

One of the possible and useful abilities in the present study is the degree of education. Perhaps a person with higher education level gives less value to the visual appearance of the potato (aspects of the skin) and considers other relevant information. The division of views between group 1 - people with significantly lower education - and the other groups may reflect the absence of this capability.

When considering aspects of the potato skin, group 1 stood out from other groups. This may indicate that selection by this group is based on easily perceived attributes (which reinforces the view that the focus is on immediate need and a lack of capacity), paving the way for studies that provide strategies for offering of French potatoes to this group of people.

In examining the mixed effects model without the groups from the cluster analysis, it is verified that not only the variables of shape, aspects of the skin and seal of quality but also the variables of region, age group and schooling, had an influence on intention to purchase (Table 6). Interestingly, the cluster analysis pointed to the importance of these sociodemographic variables.

Table 6. Mixed effect linear model for intent to purchase without the groups of the cluster analysis

\begin{tabular}{|c|c|c|c|c|c|}
\hline & Value $\beta$ & SE & DF & t-value & p-value \\
\hline Intercept $\left(\beta_{0}\right)$ & 3.390 & 0.234 & 5242 & 14.486 & 0.0000 \\
\hline Western region of Belo Horizonte & -0.269 & 0.278 & 341 & -0.967 & 0.3342 \\
\hline Northeast region of Belo Horizonte & -0.799 & 0.188 & 341 & -4.256 & 0.0000 \\
\hline Western region of Belo Horizonte & -0.730 & 0.189 & 341 & -3.870 & 0.0001 \\
\hline Age -25 to 34 & 0.580 & 0.197 & 341 & 2.938 & 0.0035 \\
\hline Age -35 to 44 & 0.470 & 0.210 & 341 & 2.232 & 0.0263 \\
\hline Age -45 to 59 & 0.189 & 0.202 & 341 & 0.935 & 0.3505 \\
\hline Age - more than 60 & 0.328 & 0.243 & 341 & 1.351 & 0.1775 \\
\hline Schooling - elementary & -0.355 & 0.172 & 341 & -2.059 & 0.0402 \\
\hline Schooling - high school & -0.012 & 0.147 & 341 & -0.080 & 0.9366 \\
\hline Schooling - higher education & 0.167 & 0.201 & 341 & 0.833 & 0.4056 \\
\hline Shape of the potato ${ }^{a}$ & 1.048 & 0.063 & 5242 & 16.715 & 0.0000 \\
\hline Aspects of the skin ${ }^{b}$ & 1.044 & 0.063 & 5242 & 16.646 & 0.0000 \\
\hline Seal of quality ${ }^{c}$ & 0.706 & 0.063 & 5242 & 11.267 & 0.0000 \\
\hline
\end{tabular}

Standard deviation: $\beta_{0}=0.77(12.4 \%)$; Residue $=5.50(87.6 \%) ;{ }^{a}$ Potato with regular shape. ${ }^{b}$ Tubercles with light, smooth and bright skin. ${ }^{c}$ Potato with seal of quality. DF $=$ Degrees of freedon. $\mathrm{SE}=$ Standard error

An analysis of the age groups shows that individuals between 35 and 44 and more than 60 are not significantly different from the age group of 16 to 24. However, the groups between 25 and 34 and 35 to 44 show an average intent to purchase when compared to the age group of 16 to 24 . 
When evaluating the level of education, it may be observed that the average level of schooling and higher education show no significant difference from elementary education; however, the lower level of education presented a lower average score of intent-to-purchase when compared to higher education.

Analyzing the random part, it is observed that most of the variation in intention to purchase is within the same individual and not between individuals.

When re-observing the characteristics of the groups established in the cluster analysis, it was found that region, age and education were the main characteristics of group 1.

The factors of potato shape, aspects of the skin and a seal of quality were very important in the composition of the score of intent-to-purchase. The information available in the images evaluated by the interviewees, such as name of cultivar and recommended culinary use, was not significant for the composition of the score of purchase intent, different from that of Contamine (2008).

In the present study, potato size was considered a factor of quality by consumers, where it was believed that small potatoes are of inferior quality. The same applies to shape and visual aspects of the skin. Light yellow potatoes with smooth skin, free from dirty and defects (sprouts and holes) which did not present a green color, were selected for purchase. Thus, the physical characteristics of potatoes determined their purchase. Similar results were found by Katundu et al. (2010).

Although $74.1 \%$ of the interviewees declared they knew the meaning of a seal of quality, it is believed that many of them did not know the real significance, as demonstrated in the study carried out by Faria et al. (2006). Many people may consider this graphical representation to be a synonym for quality. It may be that the visual appeal of the seals denotes quality, even without complete understanding of its meaning. In a study conducted by Carpenter and Larceneux (2008) on the effectiveness of seals of quality in France, the authors concluded that it is necessary to explain the meaning of the seals for consumers to favor the construction of opinions about quality. Thus, it is possible to conclude that the graphical representation of the seals of quality is already a positive factor in the purchase of potatoes; however, information on its meaning and significance should be added to this representation. In association with information on the recommended culinary use, the presence of seals of quality will favor the introduction of the French potato into the market of Belo Horizonte.

It is interesting to discuss the results of the variable "information." It was expected that if interviewees knew the recommended culinary use, the score for intent-to-purchase for the set of images presenting this information would be higher and significant because it might be interesting to use a potato to produce a desired sensory result, such as culinary use. However, this variable was not significant. Some hypotheses can be formulated to explain this result.

First, the cultural standard established for the purchase of potatoes in Brazil does not include knowledge about the recommended culinary use. The physical aspects of potatoes, such as size and characteristics of the skin, were crucial for their purchase in the market of Belo Horizonte city. Therefore, during this study, many people probably did not consider such information as good, interesting or practical.

These results reveal the need for constructing a new standard that includes knowledge about the recommended culinary use. One of the alternatives is the advertisement of cultivars by means of lectures, tasting sessions, explanatory leaflets with recipes and the marketing of identified potatoes. According to Kimura et al., (2008), there must be interaction between consumers and information. The data on cultivars and culinary use are effective only if people really know their practical benefits. In other words, the experience of consumers when consuming potatoes "soaked" in oil (high absorption during frying) indicates the need for acquisition of new concepts on the quality of potatoes.

Furthermore, the dynamics between information and consumers must be analyzed. Information is not simply a fact equally absorbed by consumers, without sensations, desires and emotions. Consumers are not abstract individuals tirelessly receiving information and absorbing all of the data conveyed to them, even without knowing exactly why they are necessary. There are some important parameters in this relation, such as the amount of information and methods of presentation (KIMURA et al., 2008), religion (JUST et al., 2007), size of the family, presence and preferences of the children in the households, concept of health (AKBAY et al., 2007), convenience and humor (PRESCOTT et al., 2002, POHJANHEIMO et al., 2010). 


\section{CONCLUSIONS}

The factors that determine the purchase of potatoes were shape (regular), skin color (smooth, light and bright) and the presence of a seal of quality.

The factor "information" was not significant, which indicates that the presence of information, such as the name of the cultivar and recommended culinary use, did not affect the purchase intent, probably because this factor is absent in the current marketing process in this location.

Therefore, the introduction of new French potato cultivars into markets such as that of Belo Horizonte city should be preceded by an educational process to prepare consumers to receive information regarding the recommended culinary use of potatoes and the final sensory quality of the preparations illustrated with these potatoes.

RESUMO: O presente trabalho teve por objetivo analisar os fatores que influenciam a compra de batatas em Belo Horizonte, Brasil, e os efeitos da oferta de diferentes cultivares francesas. Na França há uma enorme variedade de batatas, com diferentes formatos, coloração e textura da casca, além de indicação para diferentes usos culinários. Portanto, a análise de agrupamento foi realizada e um modelo de regressão linear de efeitos mistos foi ajustado para analisar os fatores que podem interferir na compra de batatas pelo consumidor em Belo Horizonte. Os fatores analisados foram o tamanho, a coloração e textura da casca, e a presença ou ausência de informações sobre nome da cultivar, uso culinário e selo de qualidade. Idade, escolaridade, região e renda foram importantes parâmetros para determinar a intenção de compra dos diferentes agrupamentos, e o formato das batatas, cor da casca e presença de selo de qualidade foram significativamente importante na análise. A presença de informações relacionadas com o nome da cultivar e uso culinário recomendado não teve efeito significativo sobre a intenção de compra. Por fim, a introdução de novas cultivares de batata franceses em mercados como o da cidade de Belo Horizonte deve ser precedida de um processo de educação para preparar os consumidores para receber informações sobre a utilização culinária recomendada de batatas.

PALAVRAS-CHAVE: Batata. Cultivares francesas. Comportamento dos consumidores. Análise de agrupamentos.

\section{REFERENCES}

ABEP (Associação Brasileira de Empresas de Pesquisa). Critério de Classificação Econômica Brasil. Disponível em: http://www.abep.org. Acesso em: 10 out 2008.

AKBAY, C.; TIRYAKY, G. Y.; GUL, A. Consumer characteristics influencing fast food consumption in Turkey. Food Control, New York, v. 18, n. 8, p. 904-913, ago. 2007.

AKERLOF, G. A.; KRANTON, R. E. Economics and identity. Quarterly Journal of Economics, Oxford, v. 115 , n. 3, p. 715-753, ago. 2000.

ARES, G.; GIMÉNEZ, A.; DELIZA, R. Influence of three non-sensory factors on consumer choise of functional yogurts over regular ones. Food Quality and Preference, New York, v. 21, n. 4, p. 361-367, jun. 2010. http://dx.doi.org/10.1016/j.foodqual.2009.09.002

CARPENTER, M.; LARCENEUX, F. Label equity and the effectiveness of values-based labels: an experiment with two French Protect Geographic Indication labels. International Journal of Consumer Studies, Hoboken, v. 32, n. 5, p. 499-507, set. 2008. http://dx.doi.org/10.1111/j.1470-6431.2008.00704.x

CONTAMINE, A. C. Marchés de la pomme de terre dans 1’Union Européenne. Cahiers Agricultures, Paris, v. 17, n. 4, p. 335-342, jul-ago. 2008.

ENNEKING, U.; NEUMANN, C.; HENNEBERG, S. How important intrinsic and extrinsic product attributes affect purchase decision. Food Quality and Preference, New York, v. 18, n. 1, p. 133-138, jan. 2007. http://dx.doi.org/10.1016/j.foodqual.2005.09.008 
FAO (Food and Agriculture Organization of the United Nations). Disponível em: http://www.fao.org/corp/statistics. Acesso em: 15 mai 2009.

FARIA, I. G.; FERREIRA, J. M.; GARCIA, S. K. Mercado consumidor de carne suína e derivados em Belo Horizonte. Arquivo Brasileiro de Medicina Veterinária e Zootecnia, Belo Horizonte, v. 58, n. 2, p. 251-256, abr. 2006. http://dx.doi.org/10.1590/S0102-09352006000200014

GREEN, P. E.; SRINIVASAN, V. Conjoint analysis in consumer research. Issues and outlook. Journal of Consumer Research, Chicago, v. 5, n. 2, p. 103-123, set. 1978. http://dx.doi.org/10.1086/208721

HARTIGAN, J. A.; WONG, M. A. Algorithm AS 136: A K-means clustering algorithm. Journal of the Royal Statistical Society, New Jersey, v. 28, n. 1, p. 100-108, jan. 1979. http://dx.doi.org/10.2307/2346830

HONKANEN, P.; FREWER, L. Russian consumer's motives for food choice. Appetite, New York, v. 52, n. 2, p. 363-371, abr. 2009. http://dx.doi.org/10.1016/j.appet.2008.11.009

JUST, D. R.; HEIMAN, A.; ZILBERMAN, D. The interaction of religion and family members' influence on food decisions. Food Quality and Preference, New York, v. 18, n. 5, p. 786-794, jul. 2007.

http://dx.doi.org/10.1016/j.foodqual.2007.01.008

KATUNDU, M.; HENDRIKS, S.; BOWER, J.; SIWELA, M. Can sequential harvesting help small holder organic farmers meet consumer expectations for organic potatoes? Food Quality and Preference, New York, v. 21, n. 4, p. 379-384, jun. 2010. http://dx.doi.org/10.1016/j.foodqual.2009.09.003

KIMURA, A.; WADA, Y.; TSUZUKI, D.; GOTO, S.; CAI, D.; DAN, I. Consumer valuation of packaged foods: interactive effects of amount and accessibility of information. Appetite, New York, v. 51, n. 3, p. 628634, nov. 2008. http://dx.doi.org/10.1016/j.appet.2008.05.054

LEVIN, J. Estatística aplicada a ciências humanas. 2. ed. São Paulo: Harbra, 1987. 392p.

MACFIE, H. J. H.; BRATCHELL, N. (1989). Designs to balance the effect of order of presentation and firstorder carry-over effects in hall tests. Journal of Sensory Studies, New Jersey, v. 4, n. 2, p. 129-148, set. 1989. http://dx.doi.org/10.1111/j.1745-459X.1989.tb00463.x

MINGOTI, S. A. Análise de dados atráves de métodos de estatística multivariada uma abordagem aplicada. Belo Horizonte, MG: UFMG, 2007. 297p.

NÚCLEO DE ESTUDOS E PESQUISA EM ALIMENTAÇÃO. Tabela Brasileira de Composição de Alimentos. 4. ed. Campinas, SP: NEPA-UNICAMP, 2011. 161p.

PINHEIRO, J.; BATES, D.; DEBROY, S.; SARKAR, D. R development core team: linear and nonlinear mixed effects models. R Package, versão 3.1-90, 2008.

POHJANHEIMO, T.; PAASOVAARA, R., LUOMALA, H.; SANDELL, M. Food choice motives and bread liking of consumers embracing hedonistic and traditional values. Appetite, New York, v. 54, n. 1, p. 170-180, fev. 2010. http://dx.doi.org/10.1016/j.appet.2009.10.004

PRESCOTT, J.; YOUNG, O.; O’NEILL, L.; YAU, N. J. N.; STEVENS, R. Motives for food choice: a comparison of consumers from Japan, Taiwan, Malaysia and New Zealand. Food Quality and Preference, New York, v. 13, n. 7-8, p. 489-495, out.-dez. 2002. http://dx.doi.org/10.1016/S0950-3293(02)00010-1

R DEVELOPMENT CORE TEAM. R: a language and environment for statistical computing. Vienna: R Foundation for Statistical Computing, 2009. Disponível em: http://www.Rproject.org Acesso em: 3 apr 2009. 
SEN, A. Desigualdade reexaminada. 2. ed. Rio de Janeiro: Record, 2008. 302p.

SVEINSDÓTTIR, K., MARTINSDÓTTIR, E., GREEN-PETERSEN, D., HYLDIG, G., SCHELVIS, R.; DELAHUNTY, C. Sensory characteristics of different cod products related to consumer preferences and attitudes. Food Quality and Preference, New York, v. 20, n. 2, p. 120-132, mar. 2009.

http://dx.doi.org/10.1016/j.foodqual.2008.09.002 